\title{
Upaya Mengurangi Genangan Banjir Di Kampus Unesa Ketintang Surabaya Dengan Parit Resapan
}

\section{Efforts to Reduce Flood Inundation at the Surabaya Ketintang Unesa Campus with Infiltration Trenches}

\author{
Indiah Kustini $^{1}$, Elizabeth Titiek Winanti ${ }^{2}$ \\ ${ }^{1}$ Jurusan Teknik Sipil, Fakultas Teknik, Universitas Negeri Surabaya, Jln. Ketintang Surabaya. Email : \\ indiahkustini@unesa.ac.id \\ ${ }^{2}$ Jurusan Teknik Sipil, Fakultas Teknik, Universitas Negeri Surabaya, Jln. Ketintang Surabaya. Email : \\ titiekwinanti@unesa.ac.id
}

\begin{abstract}
Abstrak
KampusUnesa Ketintang selalu terjadi banjir pada setiap musim penghujan. Berbagai hal telah dilakukan yaitu meninggikan jalan sarana kampus, membuat saluran drainase pada setiap tepi jalan dan areal kampus, bozem dan rumah pompa. Meskipun sudah dilakukan beberapa cara tersebut kampusketintangbagianbarat (gedung A, $B, C, D$ dan $E$ ), bila terjadi hujan deras dengan durasi 2-3 jam akan terjadi genagan setinggi $30-50 \mathrm{~cm}$. Tujuan penelitian ini untuk mengetahui penyebab banjir, besar debit banjir tahunan dan menghitung parit resapan yang dapat mengurangi genangan banjir tahunan. Jenis penelitian kwantitatip, sampel penelitian lokasi genagan di kampus Unesa Ketintang. Metode pengambilan data 1) survey kondisi saluran,bozem, rumah pompa, lokasi parit, 2) dokumentasi data sekunder, 3) menghitung nilai laju peresapan. Hasil penelitian: 1) saluran drainase berkapasitas 0,470 m3/dt, banyak semak belukar, 2) saluran yang berada di kanan kiri sepanjang jalan berkapasitas 0,312 m3/dt terdapat sedimentasi dan sampah, 3) Debit bangunan Bosem hanya menampung $0,900 \mathrm{m3} / \mathrm{dt}$, 4) rumah pompa yang berkapasitas 0,059 m3/dt banyak rerumputan dan bisa diperluas dan diperdalam, 5) Dua buah pintu pengatur kurang dioperasionalkan, sehingga air Saluran Pembuang Sekunder Wonorejo terjadi aliran balik masuk ke kampus. Total kapasitas pada saat banjir sebesar $1741 \mathrm{m3} / \mathrm{dt}$, kurang efektif. Debit pada masa ulang 5 th sebesar Q5 = 2,062 m3/dt, dapat menyebabkan banjir sebesar 0,321 m3/dt bila prasarana yang ada berfungsi. Berdasarkan percobaan jenis tanah dengan koefisien laju rembesan sebesar $K=16,266 \mathrm{~cm} / \mathrm{jam}$ atau 0,000467 m/dt. Panjang parit resapan $2518 \mathrm{~m}$ dengan ukuran lebar 1,00 m dan kedalaman 1,25 m. Lokasi penempatan parit ditinjau hasil observasi tidak mencukupi karena hanya sekitar $1.200 \mathrm{~m}$. Kekurangan penampungan banjir dibuat longstorage dengan memperdalam saluran sebelah timur bozem, lobang pipa masuk bozem ditutup, rumah pompa dibuat bozem sehingga ada 2 (dua) bozem berfungsi sebagai penampung banjir dan pintu air yang kesaluran drainase sekunder di perbatasan kampus ditutup.
\end{abstract}

Kata Kunci: Debit banjir; parit resapan; bozem

\begin{abstract}
Unesa Ketintang Campus always floods every rainy season. Various things have been done, namely elevating the campus facilities road, making drainage channels on each side of the road and campus area, bozem and pump house. Even though the methods have been carried out in a number of ways, such as the A, B, C, D and E campuses, if there is heavy rain with a duration of 2-3 hours, there will be a 30-50 cm high. The purpose of this study was to determine the causes of flooding, the amount of annual flood discharge and to calculate infiltration trenches that can reduce annual flooding. This type of quantitative research, the study sample pool location at the Unesa Ketintang campus. Data collection methods 1) channel condition survey, bozem, pump house, trench location, 2) secondary data documentation, 3) calculate impregnation rate values. The results of the study: 1) drainage channels with a capacity of $0.470 \mathrm{m3} / \mathrm{sec}$, many shrubs, 2) channels that are on either side of the road with a capacity of $0.312 \mathrm{m3} / \mathrm{s}$, there are sedimentation and rubbish, 3) Debits of the Bosem building only hold $0.900 \mathrm{m3} / \mathrm{s}, 4$ ) a pump house with a capacity of $0.059 \mathrm{~m} 3 / \mathrm{sec}$ has a lot of grass and can be expanded and deepened, 5) Two regulating gates are less operational, so that the water in the Wonorejo Secondary Sewer water occurs backflow into the campus. Total capacity at the time of flooding was $1741 \mathrm{~m} 3 / \mathrm{s}$, less effective.
\end{abstract}


Debit on the 5th birthday of $Q 5=2,062 \mathrm{m3} / \mathrm{s}$, can cause flooding of $0.321 \mathrm{~m} 3 / \mathrm{s}$ if the existing infrastructure is functioning. Based on the experiment type of soil with a seepage rate coefficient of $K=16,266 \mathrm{~cm} / \mathrm{hour}$ or $0,000467 \mathrm{~m} / \mathrm{s}$. The infiltration trench is $2518 \mathrm{~m}$ with a width of $1.00 \mathrm{~m}$ and a depth of $1.25 \mathrm{~m}$. Location of the ditch placement in terms of observation results is insufficient because only about 1,200 m. Shortages of flood retarding are made for longstorage by deepening the east channel of bozem, bozem inlet pipe is closed, pump house is made bozem so that there are 2 (two) bozem functioning as flood retainers and floodgates which the secondary drainage channel is closed at the campus border.

Keywords: Flood discharge; catchment trenches; bozem

\section{PENDAHULUAN}

Banjir dan kekeringan adalah dua kata yang bertentangan tetapi saling berhubungan, artinya ada korelasi positif antara banjir dan kekeringan. Semakin besar banjir semakin parah kekeringan. Banjir adalah luapan air hujan yang tidak dapat meresap ke dalam tanah dan tidak tertampung di badan-badan air. Banyak hal menjadi penyebab banjir, sumbernya adalah ulah manusia yang tidak lihai atau bijak dalam mengelola alam. Misalnya dalam menata guna lahan, merawat sungai, mematuhi peraturan yang sudah ditetapkan. Sumber air utama hidup dan kehidupan di bumi ini adalah air hujan, jika pada saat hujan tidak banyak bagian air hujan yang meresap ke dalam tanah (recharge) maka air tanah (yang bersarang di dalam tanah) hanya sedikit mendapat pasokan. Jika kejadian ini berlangsung terus-menerus beberapa musim penghujan saja maka muka air tanah akan terus menurun, sulit digapai oleh sebagian masyarakat untuk memenuhi kebutuhan air bersih. Ini yang disebut dengan kekeringan. Dengan alasan itu marilah kita berupaya meresapkan air hujan sebanyak mungkin ke dalam tanah (Winanti, 1995).

Kampus Unesa Ketintang juga selalu terjadi banjir pada setiap musim penghujan. Hasil pengukuran kampus Unesa Ketintang oleh Tim PTB fakultas teknik di hitung, Kampus Unesa Ketintang luasnya sekitar 25,9061 hektar, sudah terbangun untuk bangunan gedung $\pm 50 \%$, bangunan terbuka impermeable (jalan, lapangan, halaman berpaving blok $\pm 19 \%$, untuk saluran $\pm 1 \%$. Diperkirakan masih ada $20 \%$ atau 51,053 hektar atau $510530 \mathrm{~m} 2$ ruang terbuka.Bagian yang terbuka $20 \%$ ini secara alami bisa atau mampu meresapkan air hujan yang jatuh di kawasan tersebut. Namun penelitian Titiek dkk, tahun 2000 melaporkan bahwa banjir yang terjadi di kampus Ketintang selain karena curah hujan yang jatuh di kawasan kampus juga dipasok oleh aliran dari masyarakat Ketintang melalui saluran sekitar lahan Telkom, banyak berkembanya rumah penduduk sepanjang rel kereta api air menambah air limpasan atap rumah pada saat hujan deras dengan durasi yang panjang (>2 jam), saluran pembuang di selatan kampus (Kali Wonorejo) penuh, berhubung pintu air yang dipasang tidak dioperasionalkan maka terjadi alir balik, juga bozem yang sudah di buat karena juga ada nya pergantian lahan sawah untuk rumah penduduk sehingga meluap ke kampus. Berbagai hal telah di lakukan yaitu dengan meninggikan jalan sarana kampus dengan memperbesar saluran buangan bentuk persegi dengan lebar $0,50 \mathrm{~m}$ dan kedalaman 0,60 m, menutup dinding pembatas kampus dengan membuat saluran/parit bentuk trapesium lebar 0,80 $\mathrm{m}$ ketinggian 1,00 $\mathrm{m}$ dan kemiringan 2:1, memasang 2 buah pintu air lebar $0,80 \mathrm{~m}$, membuat bozem luas permukaan 2,56 ha dan rumah pompa dengan luas 0,8 ha. Meskipun sudah dilakukan dari beberapa cara tersebut kampus unesa khususnya dari lokasi gedung perpustakaan, bozem sampai gedung fakultas teknik masih terjadi banjir, bila ada durasi hujan deras 2-3 jam. Kondisi banjir di kampus Unesa memang sangat kompleks, banyak faktor yang mempengaruhi.

Perubahan pembangunan secara vertikal dari gedung Ekonomi, Mipa dan Teknik, meskipun pembangunan secara vertikal sedikit perubahan mengurangi luas daya resap air namun dengan adanya penambahan paving blok pada areal bangunan dan areal penambahan gazebo akan berdampak mengurangi daya resap air sehingga menambah genangan banjir. Tetapi sebagai ilmuwan harus berupaya sedemikian rupa apa yang bisa dilakukan (UURI No 32/2009, sambil terus menelusur mencari jalan untuk membebaskan kampus dari banjir, sekali gus menjaga keseimbangan air tanah dengan cara mengkonservasi (Winanti, 2006).

Kampus Unesa Ketintang terletak di Kecamatan Gayungan Surabaya bagian selatan. Kota Surabaya merupakan dataran rendah tepi pantai yang topografinya relative datar dengan elevasi antara 26 meter dpal.Hanya ada sedikit bagian menggelombang tinggi, yang terletak di Surabaya barat. Muka air tanah sekitar 2,80m - 5,00 m di bawah permukaan tanah. Oleh karena itu untuk menabung air hujan ke dalam tanah perlu ada 
teknologi tersendiri, misalkan dengan membuat bozem, longstrored, parit resapan. Sunjoto (1996), parit resapan dibuat selain dapat meresapkan air, menampung air hujan di ahkir musim kemarau dapat menjaga kestabilan tanah, menanggulangi defisit air tanah, memperbaiki kualitas air tanah lokal melalui pencampuran dengan pengisian air tanah yang berasal dari air hujan.

Dari masalah tersebut perlu adanya penelitian apakah parit resapan dapat sebagai alternatip untuk mengurangi banjir di Kampus Unesa Ketintang, maka diperlukan menghitung besar besar debit banjir tahunan yang menyebabkan terjadinya genangan di Kampus Unesa Ketintang, menghitung parit resapan yang dapat mengurangi genangan banjir tahunan yang sering terjadi di Kampus Unesa Ketintang.

\section{TINJAUAN PUSTAKA}

Beberapa cara menanggulangi banjir, (Suripin,351) diperlukan perhitungan hidrologi dengan menghitung data tinggi curah hujan, intensitas hujan, evaluasi luas lahan terbuka, kemiringan lahan dan saluran akibat perubahan tinggi jalan, pemasangan paving di lahan terbuka, pengembangan bangunan, survei kondisi saluran drainase, mentukan adanya sarana penampungan banjir bozem, rumah pompa, titik kontrol, perbaikan saluran yang sudah ada, pembuatan parit resapan, parit resapan dan sumur resapan dan lain lainnya.

Perkiraan besar debit banjir dapat dihitung dengan beberapa metoda, secara umum metode yang dipakai metode rasional dan metode hidrograf banjir. Berhubung data limpasan di Kampus Unesa Ketingtang tidak ada maka perkiraan besar debit banjir di hitung dengan metode rasional dengan rumus (Suripin, 79).

$\mathrm{Q}=\mathrm{C}$ I A [1], dimana $\mathrm{C}$ koefisien aliran, I adalah intensitas hujan $(\mathrm{mm} / \mathrm{dt})$ dan A adaha areal genangan banjir (m2). Analisis intensitas hujan, berhubung data hujan jangka pendek tidak tersedia, yang ada hanya data hujan harian, maka intensitas hujan dihitung dengan rumus Mononobe ( Suripin, 67).

$$
I=\frac{K_{24}}{24}\left[\frac{24}{t}\right]^{\frac{2}{3}}
$$

Curah hujan rencana dalam suatu periode ulang digunakan distribusi frekuensi. Distribusi frekuensi yang sering digunakan adalah distribusi Gumbel dan log Person III, dengan rumus sebagai berikut

$R t=\frac{1}{a} Y_{T}+b$
Distribusi Log Person III, menggunakan nilai koefisien standart $\mathrm{K}$, yang besarnya tergantung koefisien kemencengan G.

$\log X_{t}=\log \bar{X}+$ K.s

Parit resapan merupakan salah satu penanggulangan banjir dengan cara penampungan aur hujan dan dapat didibangun dengan kondisi muka air tanahnya berkisar antara 2,0 m-5,50 m dibawah permukaan tanah. Resapan air hujan di daerah rendah ditawarkan teknologi parit-parit resapan atau pipa resapan. Untuk mendapatkan ukuran penampang dan panjang parit-parit secara detail perlu dihitung diantaranya berdasarkan: daya serap tanah, curah hujan tertinggi, kedalaman muka air tanah, dan persentase luas bangunan. Parit resapan yang dinyatakan oleh Maryono, Agus (2006), berfungsi untuk menampung air aliran permukaan dan meningkatkan daya resap air ke dalam tanah. Teknologi ini sesuai untuk wilayah dengan tanah yang 1) tidak rawan longsor, 2) mempunyai kemampuan tinggi untuk meresapkan air, dan 3) yang agak dangkal (kedalaman $>2 \mathrm{~m}$ ). Parit peresapan, menurut (Arsyad 2000), dibuat mengikuti kontur dengan ukuran lebar $30-40 \mathrm{~cm}$ dan dalam $40-50 \mathrm{~cm}$.

Langkah-Iangkah yang perlu diperhatikan dalam pembuatan parit resapan air hujan SNI 8456:2017, adalah sebagai berikut: 1) Menentukan lahan untuk penempatan parit resapan, 2) menentukan tempat/lokasi parit resapan air hujan yang akan dibuat dilahan yang ada disekitar halaman depan rumah/bangunan, 3) mengukur jarak antara rencana penempatan parit resapan air hujan dengan bangunan.4) mengukur muka air tanah, 5) mengukur kedalaman muka air tanah ditempat yang akan dibuatkan parit resapan, jika kedalaman muka air tanah $\leq 2 \mathrm{~m}$, maka parit resapan dapat dibuat, 6) menentukan angka permeabilitas tanah, 7) melakukan pengujian perkolasi tanah pada kedalaman $2 \mathrm{~m}$, di lokasi dimana parit resapan akan dibuat, jika dari hasil pengujian perkolasi tanah diperoleh nilai koefisien permeabilitas tanah $\geq 2,0 \mathrm{~cm} / \mathrm{jam}$, maka dapat direncanakan parit resapan air hujan, 8) perhitungan dimensi parit resapan.

Parit resapan dapat dibuat bila angka perkolasi (PR) dari hasil pengujian baik dengan alat uji perkolasi hidrlogi maupun mekanika tanah. Waktu perkolasi adalah waktu dalam satuan menit yang diperlukan oleh air, waktu turun sedalam $2,54 \mathrm{~cm}$ (1 inchi). Hasil waktu perkolasi dinyatakan dalam menit/inchi. Kesimpulan bahwa makin lama waktu 
perkolasi, makin luas tanah peresapan yang diperlukan, atau makin lama waktu perkolasi makin luas tanah absorbsi yang diperlukan.

Data-data yang diperlukan untuk menghitung dimensi parit resapan, diperlukan data-data sebagai berikut: 1) data curah hujan harian minimal 5 tahunan untuk menghitungan intensitas hujan, 2) data luas bidang tadah yang akan digunakan sebagai pengumpul air hujan, 3) data jenis tanah/nilai koefisien permeabilitas tanah (K) dilokasi rencana parit resapan, 4) data koefisien limpasan air hujan di lokasi rencana parit resapan.

Dimensi parit resapan air hujan (m) SNI 8456:2017, dapat dihitung dengan rumus:

$\mathrm{H}=\mathrm{Q} 2 / \beta \mathrm{b} h 2 \mathrm{~K} 2$

Dimana koefisien limpasan (c) untuk bidang tanah, digunakan nilai $\mathrm{c}=0,95$,

harga $\beta=16$ untuk parit berdinding kedap air atau parit tanpa dinding dengan batu pengisi dan harga $\beta=40, \mathrm{~K}$ adalah Koefisien permeabilitas tanah $(\mathrm{m} / \mathrm{jam})$.

Koefisien permeabilitas tanah (m/jam) terkait dengan kapasitas infiltrasi adalah kemampuan tanah dalam merembeskan (menginfiltrasikan) air yang terdapat di permukaan ataualiran air permukaan kebagiandalam tanah tersebut, dengan adanya perembesan, aliran air permukaan akan sangat berpengaruh (Kartasapoetra, 1989). Kapasitas infiltrasi terjadi ketika intensitas hujan melebihi kemampuan tanah dalam menyerap kelembaban tanah. Sebaliknya, apabila intensitas hujan lebih kecil dari pada kapasitas infiltrasi, maka laju infiltrasi sama dengan laju curah hujan.

\section{METODE PENELITIAN}

Penelitian ini merupakan penelitian ilmiah yang bersifat sistematik, menggunakan variabel penelitian berupa angka dari data primer dan melakukan analisa data dengan menggunakan teori yang terkait dengan penelitian. Sebagai dasar untuk mengetahui panjang parit variabel yang harus diukur adalah besar intensitas hujan dan kapasitas infiltrasi/koefisien rembesan.

Penelitian ini dilaksmeliputi kawasan kampus Unesa di Ketintang. Data yang dikumpulkan data primer dan sekunder. Dilaksanakan dengan cara observasi, tes lapangan dan dokumentasi. Tes lapangan untuk mengetahuibesarnya koefisien resapan air sebagai syarat dapat di buat parit resapan. Koefisien resapan air ditentukan berdasarkan uji infiltrasi lapangan (uji hidrologi) dan uji jenis tanah digunakan uji rembesan metode Constand Head. Kedua uji tersebut ditentukan pada titik titik daerah genagan dengan lokasi yang sama.Sebagai sampel penelitian ini adalah titik-titik yang tergenang di kampus Ketintang.

Alat yang dipakai untuk penelitian adalah dokumentasi untuk mengetahui tinggi curah hujan, alat percobaan untuk mengetahui koefisien rembesan dan observasi kapasitas saluran.

Teknik analisis data dapat dilakukan teknik analisa data menggunakan rumus-rumus teori yang terkait dengan penelitian.

\section{HASIL DAN PEMBAHASAN}

Intensitas hujan yang menyebakan terjadinya genangan akibat banjir tahunan di kampus Unesa Ketintang ditentukan dari data hujan rerata maksimum 10 tahun terahkir lampiran 1 (satu). Data hujan tahunan diambil dari stasiun pengukuran hujan terdekat yaitu dari stasiun hujan Perak II. Intensitas hujan penyebab banjir tahunan, direncana terjadi dalam 2,5 dan 10 tahun dihitung dengan rumusmenggunakan Metode log Person Tipe III, karena hasil hitungan hujan rerata menggunakanrumus Frekwensi Gumbel, mempunyai angka koefisien Cs lebih kecil dari yang di syaratkan $\mathrm{Cs}<\mathrm{Ck} 0,1732<0,3607$.

Hasil hitungan hujan rerata dengan Metode Log Pearson Type III adalah 21.13345/10 = 2,1133 mm. Tinggi hujan rencana (SNI8456:2017), ditentukan dari tinggi hujan rencana periode 2 tahun dengan nilai $G$ dalam tabel kemencengan $\log$ Pearson 0,15, dapat dihitung: $\log \mathrm{RT} 2=\log \mathrm{Xi}$ Rerata + GxSD $=1.89486+0.195 * 0.3184=1,957$ $\mathrm{mm} /$ etmal. RT2 $=90,564 \mathrm{~mm} /$ etmal. Q2= C I A $=$ 0,90x 0,019745mm/jam x $25901.42 \mathrm{~m} 2=4613,4662$ $\mathrm{m} 3 / \mathrm{jam}=1,2815 \mathrm{~m} 3 / \mathrm{dt}$. Rencana banjir terjadi pada masa ulang 5 th yaitu sebesar: $\log$ RT5 $=\log \mathrm{Xi}$ Rerata + GxSD $=1.89486+0.84 \times 0.3184=2,136$ $\mathrm{mm} / \mathrm{etmal}$. RT5 = 145,746 mm/etmal.

Besar debit banjir yang terjadi setiap tahun di unesa kampus ketintang Surabaya adalahdiprediksi ada dua rencana (hasil hitungan di atas), yaitu Q2= $1,2815 \mathrm{~m} 3 / \mathrm{dt}$ dan Q5 = 2,062 m3/dt. Debit banjir tersebut oleh Unesa Ketintang, sudah ada upaya sarana tampungan yaitu 1) Saluran keliling kampus, 2) saluran kiri kanan jalan, 3) bangunan bozem, 4) Pompa pembuang ke saluran drainase, 2 pintu pengatur banjir. Kapasitas masing masing sarana tersebut adalah kapasitas drainase saluran tersier di keliling lokasi kampus. Hasil observasi saluran 
tersebut berbentuk trapezium dengan, demensi lebar saluran $(b)=0,80 \mathrm{~m}$, tinggi saluran $(\mathrm{h})=0,80 \mathrm{~m}$, kemiringan 1: 0,70 , Kekasaran dinding $\mathrm{k}=0,40$, kemiringan saluran $(\mathrm{I})=0,0004$, debit $=0,47$ $\mathrm{m} 3 /$ detik dengan kondisi baik namun saluran penuh ilalang seperti gambar 1
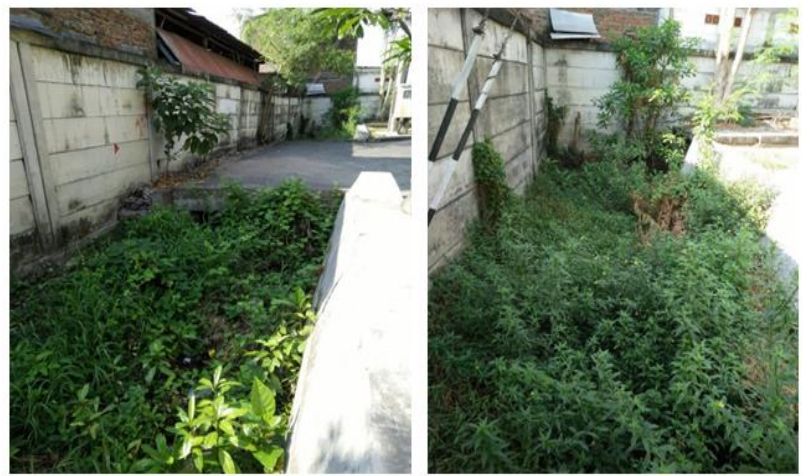

Gambar 1. Kondisi saluran tersier sekeliling kampus tertutup tumbuhan. (lokasi saluran utara gedung A8)

Kapasitas drainase saluran tersier di kanan kiri jalan lokasi kampus. Drainase saluran tersier (dua saluran) di sepanjang jalan kampus unesa dari Hasil observasi saluran berbentuk segiempat dengan, demensi: Lebar saluran $(\mathrm{b})=0,60 \mathrm{~m}$, tinggi saluran (h) $=0,80 \mathrm{~m}$, kekasaran dinding $\mathrm{k}=0,40$. Kemiringan saluran $(I)=0,0005$, debit $=1,115$ m3/detik dengan kondisi saluran baik, namun ada sedikit sampah dan sedimen seperti pada gambar 2 .
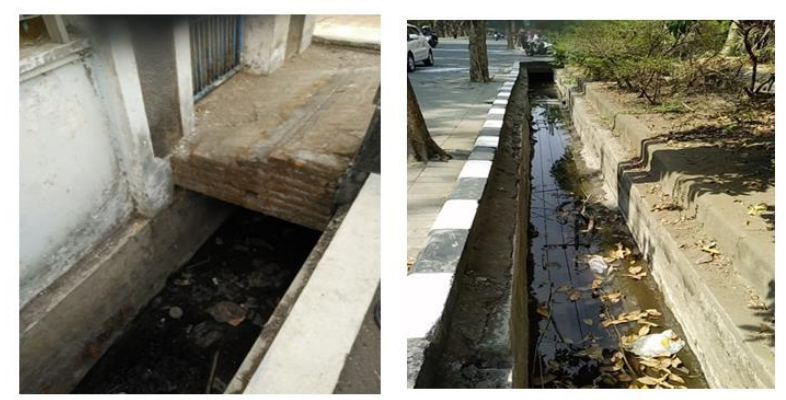

Gambar 2. Kondisi saluran tersier kanan kiri sisi kampus ketintang terdapat sedimentasi lokasi saluran sebelah barat gedung mipa dan parkir fakultas teknik

\section{Kapasitas Bozem}

Dilihat dari kondisi saluran disekitar pompa dan halaman nya kurang terawat dan operasional pompa kurang maksimum akan menyebabkan operasional tidak maksimum. Pemompaan dari Bozem berfungsi bila muka air di saluran drainase Wonerejo sudah surut, hal ini terjadi setelah hujan lebat kurang lebih 12 jam setelah hujan lebat, sehingga genamgam terjadi selama $12 \mathrm{jam}$.

Rumah pompa lokasi di utara parkir sepeda motor dari hasil survai berbentuk persegi kedalaman sekitar $1,05 \mathrm{~m}$ dan lebar $25 \mathrm{~m}$, panjang $30 \mathrm{~m}$, bentuk ini diansumsi sebagai parit resapan sehingga dapat menampung debit

Hasil hitungan kapasitas debit banjir yang di tampung dalam saluran adalah sebesar $1,741 \mathrm{~m} 3 / \mathrm{dt}$, dengan rician sebagai berikut (hasil hitungan di atas: Kapasitas Q saluran yang berlokasi dikelilng kampus $=0,470 \mathrm{~m} 3 /$ detik. Kapasitas Q saluran yang berada dikanan kiri sepanjang jalan $=0,312 \mathrm{~m} 3 /$ detik. Kapasitas Q bangunan bosem $=0,900 \mathrm{~m} 3 /$ detik. Kapasitas Q bangunan rumah pompa $=0,059$ $\mathrm{m} 3 /$ detik. Pintu Air dan saluran gorong yang masuk ke saluran drainase Wonorejo, yang berlokasi sebelah selatan pintu gerbang belakang Kampus unesa Ketintang. Kondisi pintu kurang difungsikan seperti pada gambar 4.4, saluran masuk drainase mempunyai elevasi sekitar $95 \mathrm{~cm}$ dengan elevasi deks tanggul saluran drainase. Bila kapasitas drainase saluran Wonorejo penuh muka terjadi banjir dan pintu pengatur tidak dioperasikan akan terjadi alir balik. Air balik air yang mengalir kembali ke tempat asal.

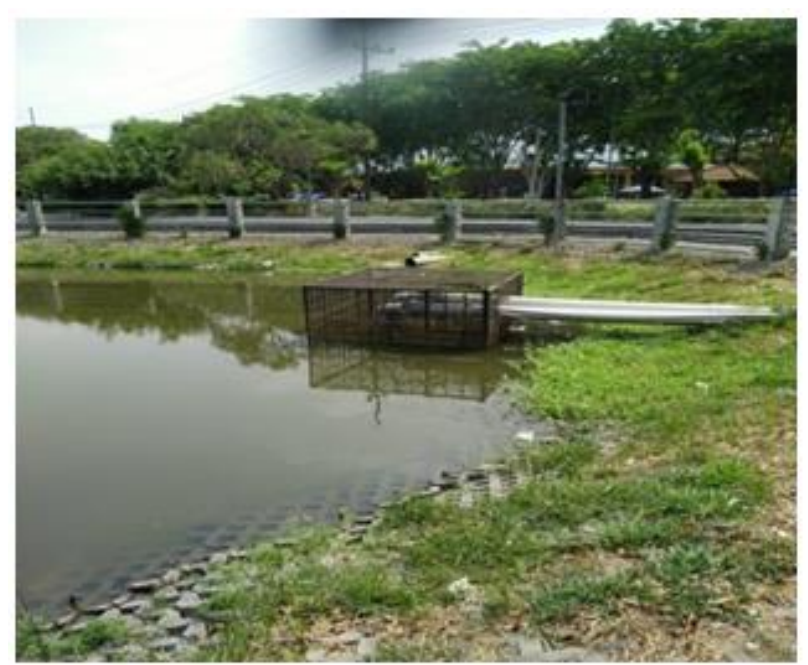

Gambar 3. Kondisi bangunan bozem di Unesa Ketintang

Pintu Air dan saluran gorong yang masuk ke saluran drainase Wonorejo, yang berlokasi sebelah selatan pintu gerbang belakang Kampus unesa Ketintang. Kondisi pintu kurang difungsikan. Saluran masuk drainase mempunyai elevasi sekitar $95 \mathrm{~cm}$ dengan elevasi deks tanggul saluran drainase. Bila kapasitas drainase saluran Wonorejo penuh muka terjadi banjir dan pintu pengatur tidak dioperasikan akan 
terjadi alir balik. Air balik air yang mengalir kembali ke tempat asal.
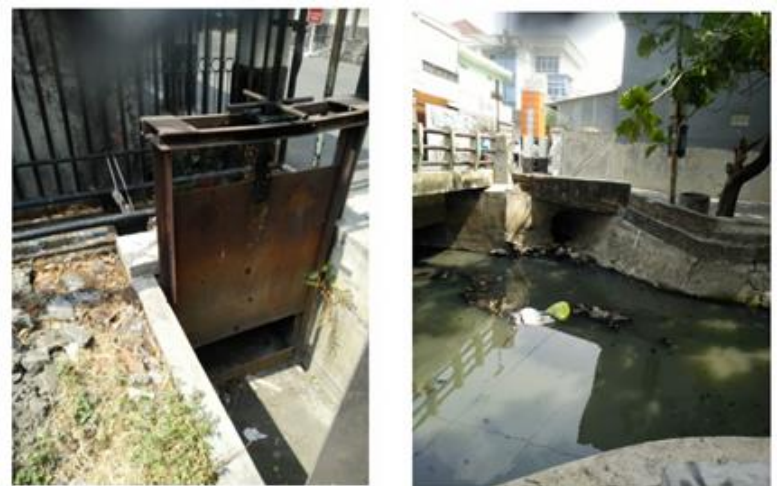

Gambar 4. Pintu air pengatur dan intake bila air penuh terjadi alir balik

SNI8456:2017, menetukan parit resapan dapat digunakan sebagai penanggulangan banjir bila, koefisien permeabilitas $>2 \mathrm{~cm} / \mathrm{jam}$, jadi sebelum mnggunakan parit resapan harus dicari nilai koefisien permeabilitas terlebih dulu.koefisien permeabilitas, diketahui dengan percobaan infiltrasi /rembesan. Besar infiltrasi untuk setiap lokasi berbeda, tergantung dari tingkat kehalusan tanah /komposisi kandungan tanah dan lokasi serta data tanaman sekitarnya.

Hasil penelitian di lokasi 1) Kebon mangga sebelah utara Gedung E, 2) Taman Depo Air Minum Unesa, 3) Taman Jurusan PKK sebelah utara Gedung A2,4) Taman Jurusan Teknik Sipil sebelah barat Gedung A4 dan 5) Taman jurusan mesin sebelah utara gedung A6 mendapatkan hasil pengamatan tersebut mempunyai system yang sama yaitu diadakan pengamatan sampai terjadi penurunan volume air/terjadi perembesan dengan waktu yang konstan. Kondisi tersebut dinamakan terjadi konstanta laju infiltrasi (k). Besar konstanta laju infiltrasi hasil rekap analisa data uji rembesan di laboratoriumdengan metode Constand Head didapatkan hasil rerata dari 5 sampel adalah $\mathrm{k}$ rerata $=16,266 \mathrm{~cm} / \mathrm{jam}$, mininimal $\mathrm{k}=13,630$ $\mathrm{cm} / \mathrm{jam}$ dan maksimum k=17,426 cm/jam. Ditinjau dari ketetapan SNI8456:2017 tentang nilai konstanta laju infiltrasi $(\mathrm{k})$ dari semua sampel> 2 $\mathrm{cm} / \mathrm{jam}$, berarti pada Kampus Unesa Ketintang mempunyai jenis tanah pasir halus dan dapat dibangun parit resapan.

Hasil rekap data dari alat infiltrometer (percobaan di lapangan) didapatkan hasil rerata dari 5 sampel adalah nilai konstanta laju infiltrasi $(\mathrm{k})=11,83$ $\mathrm{cm} / \mathrm{jam}$, mininimal $\mathrm{k}=3,50 \mathrm{~cm} / \mathrm{jam}$ dan maksimum $\mathrm{k}=17,90 \mathrm{~cm} / \mathrm{jam}$. Ditinjau dari ketetapan SNI8456:2017 tentang nilai konstanta laju infiltrasi (k) dari semua sampel $>2 \mathrm{~cm} / \mathrm{jam}$,berarti pada Kampus Unesa Ketintang juga mempunyai jenis tanah pasir halus dan dapat dibangun parit resapan. Dari dua hasil percobaan tanah di lokasi Kampus Unesa Ketintang mempunyai jenis tanah pasir dan dapat di buat parit. Nilai konstanta laju infiltrasi (k) ditentukandari hasil percobaan laboratorium karena lebih kecil kesalahannya,yaitu sebesar $\mathrm{K}=16,266$ $\mathrm{cm} / \mathrm{jam}$ atau $0,000467 \mathrm{~m} / \mathrm{dt}$.

Debit banjir genangan yang terjadi setiap tahun, bila saluran yang ada dan bangunan tidak berfungsi, sebesar $0.319 \mathrm{~m} 3 / \mathrm{dt}$, dapat menaikan terjadi genangan $0,30 \mathrm{~cm} \mathrm{~s} / \mathrm{d} 0,60 \mathrm{~cm}$. Konstanta Laju Infiltrasi ( $\mathrm{k}$ ) ditentukan dari hasil percobaan hidrologi infiltrometer adalah $0,168 \mathrm{~m} / \mathrm{jam}=$ $0,168 / 360=0,000467 \mathrm{~m} / \mathrm{dt}$. Demensi parit yang digunakan menurut ketetapan SNI 8456 :2017lebar parit (b) $=80 \mathrm{~cm}$, tinggi parit $(\mathrm{h})=1,25 \mathrm{~cm}$. Perlu pembuatan parit panjangnya $3,518 \mathrm{~km}$, rencana pembuatan parit di areal pohon mangga, lapangan, halaman depo air, halaman gedung fakultas dan halaman gedung A4.Lokasi tersebut sesuai rencana penempatan sampel kecuali untuk yang areal lapangan.

Besar debit banjir tahunan di kampus unesa, direncana berdasarkan ketentuan SNI8456:2017, yaitu menggunakan rumus rasional, banjir yang terjadi dikota, yaitu $\mathrm{Q}=\mathrm{C}$ I A, dimana intensitas hujan maksimum yang direncana 2 th, 5th. Menggunrumus Mononobame $I=(R 24 / 24)(24 / t)$ 2/3. Data hujan diambil dari stasiun hujan BMKG Perak 2 Hujan dengan pengukuran 10 tahun terahkir th $2010 \mathrm{~s} / \mathrm{d} 2019$. Hasil analisa data hujan rencana yang akan terjadi pada waktu ulang $2 \mathrm{t}$ dan 5 th , dihitung dengan Rumus Loog Person III sebesar 90,564 $\mathrm{mm}$ dan 145,746 mm. Hasil hitungan intensitas hujan dari rencana hujan tersebut dapat dihitung $1,281 \mathrm{~mm}$ dan 2,06 $\mathrm{mm}$. Selanjutnya dapat dihitung besar debit banjir Rencana Q 2= $1,281 \mathrm{~m} 3 / \mathrm{dt}$, dan Q $5=2,106 \mathrm{~m} 3 / \mathrm{dt}$.

Banjir genangandi kampus Unesa Ketintang terjadi karena 1) terjadi hujan terus menerus dengan durasi 1-2 jam maupun terus menerus dalam 2 hari, dari hasil analisa dihitung sebesar $0,535 \mathrm{~m} 3 / \mathrm{dt}, 2$ ) hasil survai pintu air outlet berlokasi di sebelah selatan fakultas teknik (gedung A1), pada saat hujan tidak ditutup sehingga ada air balik dari saluran drainase sekunder Wonorejo, 3) muka air tertinggi pada saat musim hujan pada Bozem sama dengan muka jalan,4) saluran keliling kampus tidak dirawat banyak tanaman perdu dan sedimentasi, 5) pompa baik di bangunan Bozem dan di rumah pompa, dapat diopersikan menunggu surut muka air setelah 
terjadi hujan lebih dari 1 (satu) hari mempunyai selang waktu sama, jadi baru bisa memompa setelah banjir terjadi.

Hasil hitungan debit tersebut dengan kapasitas debit sarana yang ada bila sarana tersebut berfungsi dengan baik tidak akan banjir karena: 1)Banjir rencana Q2 1,2815 m3/dt < Q kapasitas sarana yang ada di kampus ketintang 1,741 m3/dt , berati tidak menyebabkan banjir genangan. Namun kenyataan ada banjir genangan, sebagai penyebab banjir ini dapat dijelaskan karena kapasitas saluran disekeliling kampus tidak berfungsi karena banyak tanaman perdu, bozem sudah tidak dapat menampung air banjir karena elevasi muka air sudah sama elevasi banjir, meskipun elevasi masih $1 \mathrm{~m}$ di bawah tanggul bozem, mendapat pasokan air dari saluran drainase karena lobang masuk berada dalam kedalam air saluran drainase tidak diopersikan pintu air.

Tinggi genangan pada saat ini di areal jalan bagian utara bangunan bozem-gedung perpustakaan kearah selatan pintu gerbang belakang, lebih jelas ditunjukan pada Gambar 4.5 dengan luas genangan diperkirakan $5 \mathrm{ha}=5000 \mathrm{~m} 2$ selama 12 jam, debit yang tidak tertampung diansumsi debit yang berada di saluran keliling $0,312 \mathrm{~m} 3 / \mathrm{dt}$ disaluran dan pintu air di tutup, yaitu terjadi genangan sebesar: $(0,312 *$ $12 * 3600) /(50000)=0,30 \mathrm{~cm}$.Penyebab adanya genangan, meskipun sarana tampungan banjir berfungsi bila terjadi rencana banjir Q5, karena Q5 sebesar 2,062 m3/dt > Q kapasitas sarana di kampus ketintang $1,743 \mathrm{~m} 3 / \mathrm{dt}$, berarti terjadi banjir genangan sebesar $0.319 \mathrm{~m} 3 / \mathrm{dt}$, dapat menaikan genangan banjir $0,30 \mathrm{~cm}$, bila saluran yang ada dan bangunan Bozem serta pompa berfungsi, bila tidak dapat menyebabkan $0,60 \mathrm{~cm}$.

Dari dua hasil percobaan tanah di lokasi Kampus Unesa Ketintang mempunyai jenis tanah pasir dan dapat di buat parit. Nilai konstanta laju infiltrasi (k) ditentukan dari hasil percobaan laboratorium karena lebih kecil kesalahannya, yaitu sebesar $K=16,266$ $\mathrm{cm} / \mathrm{jam}$ atau $0,000467 \mathrm{~m} / \mathrm{dt}$. Panjang resapan dihitung dengan rumus yang ditetapkan di SNI 8456:2017 yaitu debit dalam m/jam dibagi dengan luas dan konstanta laju peresapan dengan hasil panjang parit resapan $2518 \mathrm{~m}$ atau $2,518 \mathrm{~km}$ dengan ukuran lebar 1,00 m dan kedalaman 1,25 m.

Lokasi parit resapan disarankan dibangun pada lahan kosong yaitu lokasi lapangan sepak bola supaya permainan sepak bola tidak terganggu hanya dibuatkan di sebelah selatan sepanjang $500 \mathrm{~m}$. Lokasi lahan tanaman manga dapat dibuat keliling sepanjang $(150+30) 2 \times 2=720 \mathrm{~m}$ dan di buat 2 saluran melintang $2 \times(0,30+0,30)=120 \mathrm{~m}$, jadi total $840 \mathrm{~m}$. Lokasi lahan tanaman pada gedung depo air juga di buat keliling sepanjang $(10+30) \mathrm{x}$ $2=80 \mathrm{~m}$. Lokasi gedung A4 juga dibuat keliling sepanjang $80 \mathrm{~m}$ untuk gedung fakultas bagian barat daya juga $80 \mathrm{~m}$,

Sebagai alternatif penampungan debit banjir tersebut dapat di buang pada bozem karena pada saat banjir bozem masih ada ketinggian $1 \mathrm{~m}$ dari tanggul, dengan menutup saluran intake bozem dan menambah pompa lagi satu untuk menyedot air dari saluran sebelah utara bozem, dibuat long storet. Gambar parit dan lokasi parit seperti yang ditunjukan pada gambar berikut.

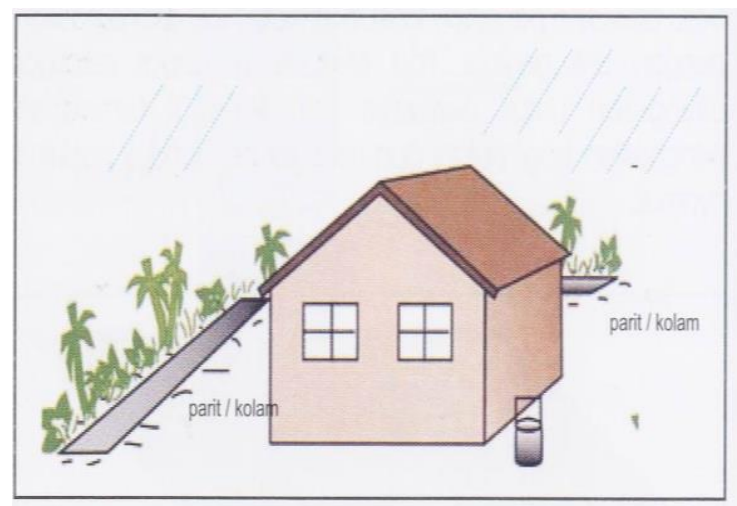

Gambar 5. Ilustrasi tipe parit

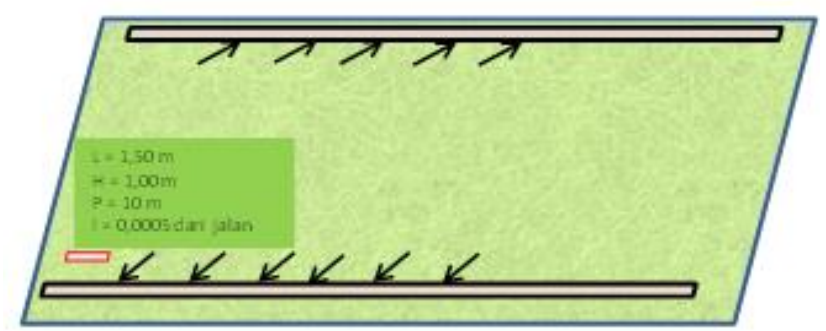

Gambar 6. Lokasi parit di lapangan sepak bola

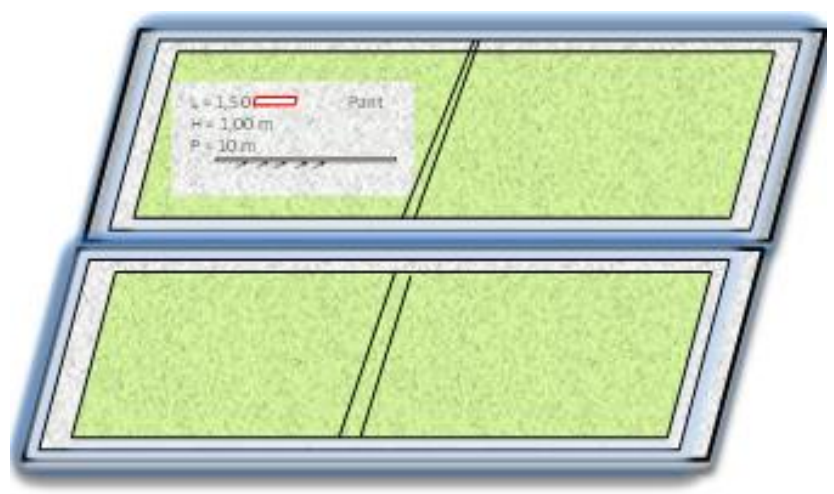

Gambar 7. Lokasi parit di sekeliling gedung E2 dan parkir 


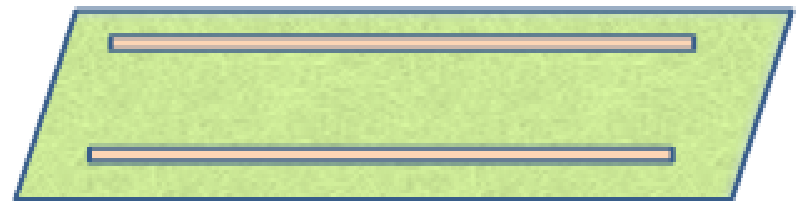

Gambar 8. Lokasi parit disebelah barat laut fakultas

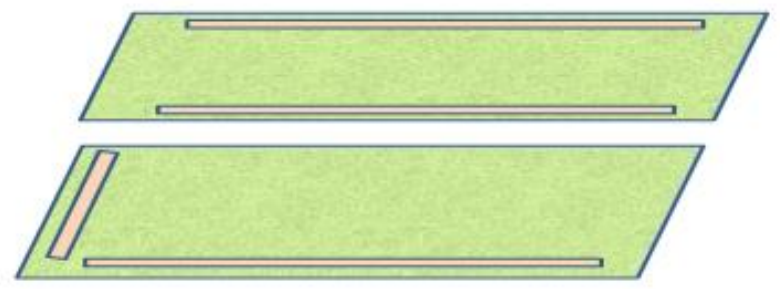

Gambar 9. Lokasi parit di taman sebelah selatan dan barat gedung A4

\section{KESIMPULAN}

Besar debit banjir tahunan yang menyebabkan terjadinya genagan di Kampus Unesa Ketintang terjadi pada masa ulang 5 tahun sebesar 2,062 $\mathrm{m} 3 / \mathrm{dt}_{\text {s }}$ akan ditampung oleh sarana saluran drainase keliling kampus, saluran kiri kanan jalan yang ada di kampus dan bangunan bozem serta rumah pompa sebesar $1,743 \mathrm{~m} 3 / \mathrm{dtjadi}$ tinggal $0,319 \mathrm{~m} 3 / \mathrm{dt}$.

Dimensi parit resapan yang dapat mengurangi genangan banjir tahunan yang sering terjadi di Kampus Unesa Ketintang dengan nilai konstanta laju resapan $\mathrm{k}=16,266 \mathrm{~cm} / \mathrm{jam}$ atau 0,000467 $\mathrm{m} / \mathrm{dt}$, demensi dibuat lebar $1,00 \mathrm{~m}$, tinggi $1,25 \mathrm{~m}$ dapat dihitung panjang parit 2518 matau $2,518 \mathrm{~km}$. Rencana lokasi a) lapangan sepak bola dibuat di sebelah utara sepanjang $500 \mathrm{~m}$, berjajar dengan dinding pembatas dengan lapangan tenis, b) Lokasi lahan tanaman manga 2 tempat dapat dibuat keliling dari lahan dan 2 saluran melintang sepanjang 840 $\mathrm{m}, \mathrm{c})$ Lokasi lahan tanaman pada gedung depo air, taman di sebelah barat gedung A4, taman sebelah barat daya gedung fakultas masing masin $80 \mathrm{~m}$. juga di buat keliling sepanjang $80 \mathrm{~m}$, lokasi gedung A4 juga dibuat keliling sepanjang $80 \mathrm{~m}$ untuk gedung fakultas bagian utara juga $80 \mathrm{~m}$, masih kurang $2 \mathrm{~km}$ dapat dibuat saluran penampung dengan memperdalam saluran (long storage) sebelah utara bozem dengan membuat pompa masuk pada bozem dan menutup lobang masuk bozem dan merubah rumah pompa menjadi Bozem, karena kurang berfungsi. Untuk mengurangi genangan ada pembersihan tanaman perdu dan sedimen pada sarana saluran yang sudah di bangun, baik di sekeliling kampus dan saluran tepi jalan sarana kampus. Pintu air yang ada di intake saluran sekunder Wonorejo sebaiknya pada musim hujan dengan tanda ada awan gelap segera ditutup. Sarana parit resapan yang dibuat, sebaiknya diatasnya dibuatkan deruji di pasang melintang saluran /parit resapan supaya tidak membahayakan bila ada pejalan kaki yang bermain

\section{REFERENSI}

Triatmojo, Bambang. 2009. "Hidrologi Terapan". Beta offset: Yogyakarta

Chorley, R.J. 1969. "Introduction to Physical Hydrology". Munchen and Co. Ltd., New York.

Endah Noor, Mochtar Indrasurya B. 1995. "Mekanika Tanah jilid 1". Erlangga: Jakarta

Kusnaedi. 2003. "Sumur dan Parit Resapan Untuk Permukiman Perkotaan Dan Pedesaan. Penebar Swadaya". Jakarta.

Maryono, Agus. 2006. "DKI Perlu Tingkatkan Peresapan Air Hujan dan Konservasi Air tanah". Harian KOMPAS 4 Maret 2006, Jakarta.

Rosyid Harjadi. 1988." Seluruh Kota Pantai Utara Jawa tercemar Air Laut". Harian sore Surabaya Post 16 januari 1988.

Sitanala Arsyad. 2000. "Konservasi Tanah dan Air”. IPB Press: Bogor.

Sunjoto. 1996. "Hidrologi Sumur Resapan". Kursus Singkat Hidrologi Perkotaan 1, Pusat Antar Uni versitas UGM Yogyakarta.

SNI8456. 2017. "Sumur dan parit resapan airhujan". Badan Standardisasi Nasional ICS91.140.60

Todd, David Keith. 1980. "Groundwater Hydrology”. John Wiley and Sons.Inc, New York.

Thornthwaite dan Manther, J .R. 1957."Introduction and Tables for Computing Potenti al Evapotran spiration, the Water Balance". Publication in Climatology.Volume X, No.3. Certerton, New Jersey.

Ttitek Winanti. 2009. "Makna Air hujan untuk Hidup dan Kehidupan.Naskah ilmiah pidato pengukuhan sebagai guru Besar dalam Ilmu Lingkungan, di hadapan rapat Senat Terbuka Universitas Negeri Surabaya". Unipress: Surabaya.

Anonim. 2008. "Konservasi Air Tanah”. Unipress: Surabaya.

Anonim. 1996. "Mewaspadai Kualitas dan Kuantitas Air Tanah di Kotamadya Surabaya Dalam Era Industrialisasi”. Pidato ilmiah disajikan di depan rapat terbuka Senat IKIP Surabaya pada Dies Natalis XXXII 21 Desember 1996. 